УДК 541.6

\title{
Aerobic Bioprocessing of Ethanol Lignin from Abies Sibirica Wood
}

\author{
Ivan P. Ivanov*a, Margarita I. Teremova ${ }^{\mathrm{b}}$, \\ Anna O. Eremina ${ }^{a}$, Valentina V. Golovina ${ }^{a}$, \\ Irina V. Korol'kova ${ }^{a}$ and Nikolay V. Chesnokov ${ }^{\mathrm{a}}$ \\ ${ }^{a}$ Institute of Chemistry and Chemical Technology SB RAS \\ FRC "Krasnoyarsk Science Center SB RAS" \\ 50/24 Akademgorodok, Krasnoyarsk, 660036, Russia \\ ${ }^{b}$ Krasnoyarsk Science Center SB RAS \\ 50 Akademgorodok, Krasnoyarsk, 660036, Russia
}

Received 12.01.2017, received in revised form 11.03.2017, accepted 22.04.2017

The influence of the aerobic impact by microscopic fungi (Penicillium, Actinomicetus and Aspergillus), strains of bacterias (Pseudomonas sp.; Agrobacterium sp.; Bacillus subtilis; Acinetobacter calcoaceticus ВКПМ В-4833) and mixed cultures of fungi and bacteria on the bioconversion of ethanol-lignin from Abies Sibirica wood was studied. The properties of solid products of aerobic impact by these microorganisms on ethanol-lignin were compared.

Keywords: ethanol-lignin, bioprocessing, conversion, Abies Sibirica wood.

DOI: $10.17516 / 1998-2836-0022$.

(C) Siberian Federal University. All rights reserved

* Corresponding author E-mail address: ivanov@icct.ru 


\title{
Аэробная биопереработка
}

\section{этаноллигнина древесины пихты сибирской}

\author{
И.П. Иванов ${ }^{\text {a }, ~ М . И . ~ Т е р е м о в а ~}{ }^{\tilde{0}}$, А.О. Еремина ${ }^{a}$, \\ В.В. Головина ${ }^{a}$, И.В. Королькова ${ }^{a}$, Н.В. Чесноков ${ }^{a}$ \\ ${ }^{a}$ Институт химии и химической технологии СО РАН \\ ФИЦ «Красноярский научный иентр СО РАН» \\ Россия, 660036, Красноярск, Академгородок, 50/24 \\ ${ }^{\sigma}$ Красноярский научный иентр СО РАН \\ Россия, 660036, Красноярск, Академгородок, 50
}

Изучено влияние аэробного воздействия древесноразрушающих микроскопических грибов (Penicillium, Aspergillus и Actinomicetus), бактерий (Pseudomonas sp.; Agrobacterium sp.; Bacillus subtilis и Acinetobacter calcoaceticus ВКПМ B-4833) и сметанных культур грибов и бактерий на биоконверсию этаноллигнина, выделенного из древесины пихты сибирской. Проведено сравнение состава полученных твердых продуктов биопереработки этаноллигнина этими микроорганизмами.

Ключевые слова: этаноллигнин, биопереработка, конверсия, древесина пихты сибирской.

\section{Введение}

Красноярский край располагает уникальными лесными запасами: покрытая лесами площадь $(105,1$ млн га) составляет $45 \%$ от всей территории края $[1,2]$. Однако при существующих способах переработки древесного сырья в нашем регионе используется в лучшем случае лишь третья часть биомассы дерева [3]. Значителен объем отходов, которые в настоящее время складируют в отвалы или сжигают, что приводит к значительному загрязнению окружающей среды. Поэтому остро стоит вопрос утилизации древесных отходов. В последние десятилетия большое внимание уделяется поиску путей полного и рационального использования всей органической массы древесины.

Одним из способов переработки отходов лесозаготовительных и деревообрабатывающих предприятий может быть микробиологическая деградация растительных материалов, одной из основных частей которых является лигнин [4-7]. Известно, что по сравнению с другими растительными компонентами древесины биодеструкция лигнина протекает наиболее трудно $[8,9]$. Биологическими агентами, разрушающими структуру лигнина, могут служить некоторые бактерии, микроорганизмы почвы и воды, дереворазрушающие грибы [8-22].

В [11] показано, что при культивировании микроорганизмов Pseudomonas. aeroginosa, Serrata marcescens, Pandora norimbergensis LD001, Pseudomonas sp. LD002 и Bacillus sp. $L D 003$ деградация лигнинсодержащих субстратов случается не раньше чем на 4-6 сут. Была обнаружена способность бактерий Azospirillum brasilense sp.7 и Azospirillum brasilense sp.245 к деструкции лигнина с помощью внеклеточного фермента лигнинпероксидазы, выделенного в чистом виде [12]. 
Ускоренное разрушение древесных полимеров (на примере древесных опилок) осуществлено в присутствии микромицета Fusarium sp. и Aspergillus fumigatus var. griseobruneus. При твердофазном культивировании указанных микроорганизмов в течение 8 сут убыль лигнина составила от 9,4 до 10,2 \% абс. [13].

В [9 и 14] показано, что базидиомицеты могут иметь высокую способность к глубокому превращению лигнина. Так, при твердофазном культивировании дереворазрушающих грибов (возбудителей «белой гнили») базиодиомицетов Coriolus hirsutus и Cerrena maxima получены гуминоподобные вешества (с выходом 1,28-2,26 \% от массы потребленного растительного субстрата), которые в своем составе имеют ароматические фрагменты и близки к классу почвенных гуминовых кислот [15]. Было выдвинуто предположение о том, что гуминоподобные вещества образуются из разрушенных макромолекул лигнина в присутствии лакказы, активными продуцентами которой являются использованные микроорганизмы $[16,17]$.

Известен способ биоконверсии лигнина древесины, заключающийся в том, что в древесные опилки вносят инокулят лигноразрушающего гриба Panus tigrinus [18]. При культивировании указанного гриба на сосновых и березовых опилках конверсия лигнина в течение 9-14 сут составила 22,5-24,0\% [19].

Проведена биоконверсия сухих растительных остатков (древесных опилок, щепы, соломы) в присутствии разновидности того же гриба (Panus tigrinus BKM F-3616D) при температуре 24-26 ${ }^{\circ} \mathrm{C}$, аэрации воздуха, продолжительности 9-14 сут [20]. При внесении инокулята из расчета 4 л на 1 кг растительного субстрата конверсия лигнина составила 31-33 и 41-43 \% для березовых и сосновых опилок соответственно. Было установлено, что предварительная обработка сырья ультразвуком частотой 22-24 кГц в течение 10-15 мин позволяет увеличить конверсию лигнина на 15-20\%.

В [21] препарат лигнина, полученный из опилок древесно-стружечных плит на основе фенолформальдегидных и карбамидных смол сернокислотным и диоксановым методами, был подвержен деструкции под действием Aspergillus fumigatus, а также Stemphylium verruculosum и Paecilomyces carneus. Отмечено, что наибольшую скорость роста, а значит, и наибольшую скорость деструкции лигнина показал гриб Aspergillus fumigatus. Максимальная скорость роста была достигнута на среде с сернокислотным лигнином, полученным из карбамидных древесно-стружечных плит.

В [22] предложена схема окислительной деструкции лигнина коры лиственницы сибирской, луба коры березы повислой и диоксанлигнинов, выделенных из вышеперечисленного сырья. Показано, что при твердофазной ферментации сырья под воздействием штамма «МГ-97/6» Trichoderma asperellum Samuels ВКПM F-765, взятого из почвы Маганского лесопитомника, происходит увеличение числа общих гидроксильных групп в 1,2-1,4 раза, а также разрыв ароматического кольца в структурах лигнина в сочетании с окислением первичного гидроксила до карбоксильной группы.

Несомненный научный и практический интерес представляют исследования, направленные на изучение возможности предварительной биотехнологической делигнификации древесины при ее подготовке к дальнейшей переработке, например, для получения целлюлозы. 
Целью настоящей работы являлось изучение влияния аэробной биопереработки этаноллигнина, выделенного из древесины пихты сибирской, на интенсивность его биоконверсии и характеристики образующихся твердых продуктов.

\section{Экспериментальная часть}

В качестве исходного сырья для получения этаноллигнина (ЭЛ), который подвергали в дальнейшем аэробной биотехнологической переработке, использовали стволовую часть древесины пихты сибирской (Abies sibirica), предварительно освобожденную от коры. Подготовленную древесину пихты измельчали первоначально на крупные опилки, а затем в роторной мельнице РМ-120 до частиц размером менее 0,5 мм. Полученные опилки сушили в сушильном шкафу при температуре $105{ }^{\circ} \mathrm{C}$ до постоянной массы. Содержание основных компонентов древесины пихты составляло (\% от массы абсолютно сухой древесины): целлюлоза 49,8; лигнин 29,6; гемицеллюлозы и уроновые кислоты 14,9; экстрактивные вещества 6,0.

Получение ЭЛ проводили методом органосольвентного фракционирования [23, 24] опилок древесины пихты в среде водного раствора этанола с концентрацией 60 \% об. в реакторе автоклавного типа объемом 2 л, выполненном из нержавеющей стали.

Для этого 100 г опилок помещали в автоклав, добавляли 1 л водного раствора этанола и тщательно перемешивали. Автоклав герметизировали, троекратно продували потоком аргона для удаления воздуха, нагревали до температуры $200{ }^{\circ} \mathrm{C}$ (скорость нагрева 8 \%мин), выдерживали при данной температуре в течение 3 ч. Затем реактор охлаждали до комнатной температуры, содержимое автоклава фильтровали на воронке Бюхнера при пониженном давлении. Твердый остаток на фильтре промывали водным раствором этанола той же концентрации, что и реакционный раствор. Профильтрованный щелок и промывные воды объединяли, охлаждали до $4{ }^{\circ} \mathrm{C}$ и выделяли из раствора ЭЛ по методике, описанной в [25]. Для этого в емкость с полученным раствором добавляли дистиллированную воду из соотношения 3 массовые части охлажденной воды (до $4{ }^{\circ} \mathrm{C}$ ) к 1 части фильтрата с промывными водами. Для укрупнения осаждающегося ЭЛ вышеуказанную емкость выдерживали при комнатной температуре в течение 12 ч. Затем укрупненный ЭЛ фильтровали на воронке Бюхнера при пониженном давлении, промывая дистиллированной водой, сушили при $50{ }^{\circ} \mathrm{C}$ в сушильном шкафу до постоянной массы. Выход ЭЛ составил 9,5 \% мас. в расчете на абсолютносухую древесину.

Для проведения исследований по биотехнологической переработке ЭЛ в аэробных условиях был осуществлен предварительный подбор и выделение смешанных культур микроорганизмов, в состав которых включили как виды дереворазрушающих грибов, так и штаммы бактерий. Образцы для выделения микроорганизмов были отобраны из разложившихся древесных отходов и почвопокровного слоя. Для этого навески (10-20 г) вышеуказанных материалов помещали в 200 мл стерильной воды, перемешивали и через 20 мин жидкую фракцию добавляли в колбы с питательными средами. Культивировали на качалке при температуре $28{ }^{\circ} \mathrm{C}$ и 130 об/мин в течение 4 сут для наращивания бактерий и 15 сут для выделения грибов. Инокулят для работы выращивали при перемешивании в течение 5 сут на колбах объемом 500 мл с добавлением 1 г ЭЛ, 10 г глюкозы и 0,1 г танина.

В качестве инокулята были использованы следующие варианты смешанных культур микроорганизмов: микроскопические грибы (Penicillium и Aspergillus), бактерии (Pseudomonas

$$
-253-
$$


sp., Pseudomonas sp. + Agrobacterium sp.; Pseudomonas sp. + Actinomicetus; Pseudomonas sp.+ +Bacillus subtilis + Acinetobacter calcoaceticus BКПM B-4833), грибы + бактерии (Pseudomonas sp. + Agrobacterium sp. + Penicillium) .

Эксперименты по биотехнологической переработке ЭЛ проводили в ферментерах объемом 2 л с постоянным перемешиванием и аэрацией воздухом, поддерживали температуру от 32 до $35^{\circ} \mathrm{C} ; \mathrm{pH}$ среды 6,5-7,0. В ферментер вносили 400 мл солевой среды; 200 мл инокулята; 5 г ЭЛ; 0,1 г пептона; 0,5 г крахмала. Состав солевой среды (г/л): $\left(\mathrm{NH}_{4}\right)_{2} \mathrm{SO}_{4-} 2,0 ; \mathrm{KH}_{2} \mathrm{PO}_{4-} 1,0 ; \mathrm{MgSO}_{4}-$ 0,$2 ; 5$ мл раствора микроэлементов (состав в г/л): $\mathrm{FeCl}_{3} \cdot 6 \mathrm{H}_{2} \mathrm{O}-5,4 ; \mathrm{ZnSO}_{4}-1,44 ; \mathrm{MnSO}_{4}-1,11$; $\mathrm{CuSO}_{4} \cdot 5 \mathrm{H}_{2} \mathrm{O}-0,25 ; \mathrm{CoSO}_{4} \cdot 7 \mathrm{H}_{2} \mathrm{O}-0,28 ; \mathrm{pH}$ среды 6,7-7,0. Продолжительность биопереработки 8 сут.

Эксперименты по биопереработке этаноллигнина в присутствии смешанной культуры бактерий, состоящей из бактерий рода Pseudomonas sp., Bacillus subtilis и штамма Acinetobacter calcoaceticus BKПМ B-4833: продолжительность процесса варьировали - 24, 48, 60 ч.

После выгрузки из ферментера продукты биомодификации ЭЛ сушили в сушильном шкафу камерного типа с принудительной вентиляцией при температуре $50{ }^{\circ} \mathrm{C}$ до постоянной массы.

Конверсию этаноллигнина в процессе аэробной биопереработки осуществляли по стандартной методике, описанной в [26]. Содержание углерода, водорода определяли на автоматическом анализаторе Flash EA-1112, Thermo Quest. Проводили расчет выход ГПВ, содержания углерода и водорода на сухую беззольную массу (daf) исследуемых образцов.

Рассчитывали степень превращения (K, \%) и скорость конверсии (X, г/ч) этаноллигнина:

$$
\mathbf{K}=\frac{\left(m_{o}-m_{t}\right)}{m_{o}} \cdot \mathbf{1 0 0}, \quad \mathbf{X}=\frac{\left(m_{o}-m_{t}\right)}{t}
$$

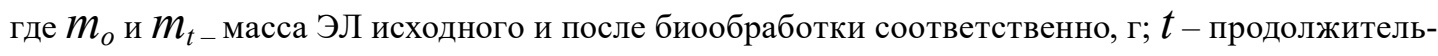
ность биообработки, ч. Определение лигнина в образцах проводили по стандартной методике [27].

Регистрацию ИК-спектров исходного лигнина и продуктов его биопереработки осуществляли на ИК-Фурье-спектрометре Tensor 27 (Bruker, Германия) в области 4000-700 см-1. Спектральная информация обработана с использованием пакета программ OPUS, версия 5.5. Образцы для съемки ИК-спектров готовили в виде таблеток в матрице бромистого калия. Условия приготовления образцов (время перемешивания с бромистым калием, давление прессования, время вакуумирования) одинаковы. Концентрация вещества постоянна и составляет 5 мг вещества/1000 мг KBr. Расшифровку ИК-спектров выполняли в соответствии с [28-33].

\section{Результаты и обсуждение}

Этаноллигнин, полученный в результате органосольвентного фракционирования (в среде водного раствора этанола) из пихты сибирской, имел следующие характеристики: $C^{\text {daf }}$ 67,9 \% масс.; $\mathrm{H}^{\mathrm{daf}}$ - 6,0 \% масс.; $\mathrm{O}^{\mathrm{d}}$ - 26,1 масс. \%; атомные соотношения: H/C - 1,07; O/C - 0,29.

При вариации используемых микроорганизмов в процессе аэробной биопереработки этаноллигнина древесины пихты в погружной среде было установлено (табл. 1), что при воздействии смеси микроскопических грибов Penicillium и Aspergillus (1) в течение 8 сут конверсия ЭЛ оказалась самой низкой - 19,3 масс. \%. 
Таблица 1. Основные характеристики продуктов аэробной биопереработки этаноллигнина

\begin{tabular}{|c|c|c|c|c|c|c|}
\hline \multirow{2}{*}{$\begin{array}{l}\text { Образец микроорганизмов } \\
\text { (номер образца) }\end{array}$} & \multirow{2}{*}{$\begin{array}{l}\mathrm{C}^{\mathrm{daf}} \\
\%\end{array}$} & \multirow{2}{*}{$\begin{array}{l}\mathrm{H}^{\mathrm{daf}} \\
\%\end{array}$} & \multicolumn{2}{|c|}{$\begin{array}{l}\text { Атомные } \\
\text { соотношения }\end{array}$} & \multirow{2}{*}{$\begin{array}{l}\text { Конверсия ЭЛ, } \\
\text { масс. \%, на daf }\end{array}$} & \multirow{2}{*}{$\begin{array}{l}\text { Скорость } \\
\text { конверсии } \\
Э Л, ~ г / ч \times 10^{-3}\end{array}$} \\
\hline & & & $\mathrm{H} / \mathrm{C}$ & $\mathrm{O} / \mathrm{C}$ & & \\
\hline Penicillium + Aspergillus (1) & 70,8 & 3,8 & 0,64 & 0,27 & 19,3 & 3,9 \\
\hline $\begin{array}{l}\text { Pseudomonas sp. }+ \text { Agrobacterium sp. }+ \\
+ \text { Penicillium ( } 2)\end{array}$ & 64,9 & 5,7 & 1,05 & 0,34 & 23,8 & 4,9 \\
\hline Pseudomonas sp. (3) & 57,3 & 6,1 & 1,28 & 0,48 & 37,4 & 8,9 \\
\hline Pseudomonas sp. + Actinomicetus (4) & 51,8 & 5,8 & 1,34 & 0,62 & 38,4 & 8,4 \\
\hline Pseudomonas sp. + Agrobacterium sp. (5) & 67,1 & 6,1 & 1,09 & 0,30 & 32,1 & 6,6 \\
\hline \multirow{3}{*}{$\begin{array}{ll}\text { Pseudomonas sp. }+ \text { Bacillus subtilis } & (6)^{*} \\
+ \text { Acinetobacter calcoaceticus } & (7)^{*} \\
\text { ВКПM В-4833 } & (8)^{*}\end{array}$} & 58,8 & 6,2 & 1,27 & 0,45 & 30,8 & 67,5 \\
\hline & 61,2 & 5,9 & 1,16 & 0,40 & 31,5 & 33,8 \\
\hline & 64,7 & 6,2 & 1,15 & 0,34 & 32,7 & 27,1 \\
\hline
\end{tabular}

* - продолжительность процесса: 6 - 24 ч; 7 - 48 ч; 8 - 60 ч.

Биопереработка ЭЛ с применением смешанными культурами бактерий и грибов в аналогичных условиях показало, что при использовании инокулята смеси состоящей из бактерий Pseudomonas sp. и Agrobacterium sp. с добавлением низших грибов Penicillium конверсия ЭЛ несколько возросла и составила 23,8 масс. \% (образец 2).

Использование инокулята, состоящего из бактерий Pseudomonas sp. и Agrobacterium sp., позволило за 8 ч повысить конверсию этаноллигнина до 32,1 масс. \%.

Под действием инокулята из бактерий Pseudomonas sp. и грибов Actinomicetus в течение 8 сут конверсия этаноллигнина увеличилась и достигла максимального значения $-38,4$ масс. $\%$ (образец 4).

Следует отметить, что близкая конверсия этаноллигнина пихты (37,4 масс. \%) была достигнута при использовании для аэробной биопереработке инокулята, содержащего только бактерии Pseudomonas sp. При этом для этого образца была определена максимальная скорость конверсии этаноллигнина $\left(8,9 \cdot 10^{-3} \Gamma /\right.$ ч) относительно образцов, полученных при продолжительности процесса биопереработки 8 сут (табл. 1).

Результаты свидетельствуют о том, что использование смесей инокулятов грибов и бактерий в сочетании с бактериями Pseudomonas sp. в условиях погружной среды не приводит к существенному повышению конверсии этаноллигнина относительно образцов, полученных при использовании инокулята, содержащего только бактерии Pseudomonas sp.

Изучение возможности использования инокулята смешанной культуры бактерий, состоящего из Pseudomonas sp. + Bacillus subtilis + Acinetobacter calcoaceticus BКПМ B-4833, позволило достигнуть сопоставимую конверсию этаноллигнина 30,8, 31,5 и 32,7 масс. \% (табл. 1, образцы 6, 7 и 8). Однако следует отметить, что эти показатели были выявлены при существенном уменьшении продолжительности процесса аэробной биопереработки от 8 сут до 24-60 ч. Полученные данные показали, что скорость конверсии ЭЛ в присутствии вышеуказанных микроорганизмов достигает своего максимального значения $\left(67,5 \cdot 10^{-3} \Gamma /\right.$ ч) в первые 24 ч и при дальнейшем увеличении продолжительности процесса 48 и 60 ч снижается до 33,8 и 27,1・10-3 г/ч соответственно. 


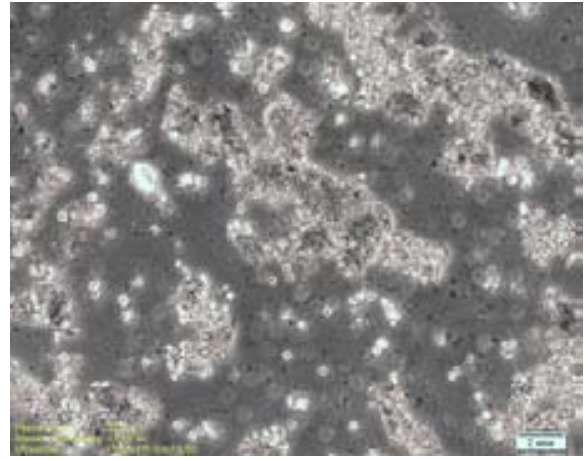

1

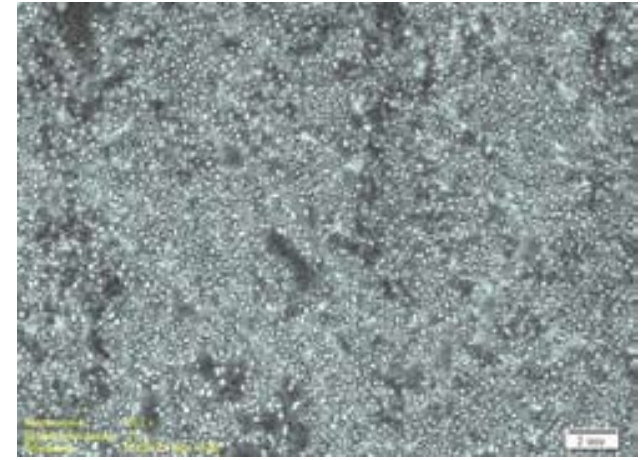

2

Рис. 1. Микрофотографии образца этаноллигнина: 1 - начальный период обработки смешанной бактериальной культурой бактерий Pseudomonas sp. + Bacillus subtilis + Acinetobacter calcoaceticus ВКПМ В-4833; 2 - после биообработки в течение 24 ч

На рис. 1 представлены микрофотографии начального и конечного периодов аэробной биопереработки ЭЛ смешанной бактериальной культурой, относящейся к родам Pseudomonas sp. + Bacillus subtilis + Acinetobacter calcoaceticus ВКПM B-4833 (образец 6). Наблюдаемая высокая плотность микроорганизмов и появление мелкодисперсной фракции ЭЛ наглядно иллюстрируют, что в процессе жизнедеятельности микроорганизмов идет активная деструкция ЭЛ, одновременно с которой происходит рост количества белковой массы за счет увеличения численности бактерий.

Результаты определения элементного состава (табл. 1) продуктов аэробной биопереработки ЭЛ в течение 8 сут свидетельствуют о том, что наибольшее содержание углерода (70,8 масс. \%) отмечено для продукта, подвергнутого аэробной биопереработке смесью микроскопических грибов Penicillium + Aspergillus (образец 1). Для указанного образца наблюдали также наименьшие значения конверсии и скорости конверсии ЭЛ.

Наиболее значительное уменьшение содержания углерода в продуктах биопереработки ЭЛ определено для образца 4 (инокулят Pseudomonas sp. + Actinomicetus), для которого установлена максимальная конверсия ЭЛ (38,4% масс.), что сопровождается достижением наиболее высокого содержания кислородсодержащих веществ и характеризуется величиной атомного соотношения $\mathrm{H} / \mathrm{C} 1,34$ и $\mathrm{O} / \mathrm{C} 0,62$.

Для образцов 6, 7 и 8, полученных в процессе аэробной биопереработки этаноллигнина инокулятом, состоящем из смеси бактерий Pseudomonas sp., Bacillus subtilis и Acinetobacter calcoaceticus ВКПМ B-4833, характерно снижение содержание кислородсодержащих соединений (снижение атомного соотношения $\mathrm{O} / \mathrm{C}$ от 0,45 до 0,34 ) при увеличении продолжительности процесса от 24 до 48 и 60 ч. При этом конверсия ЭЛ увеличивается незначительно и достигает значений $30,8,31,5$ и 32,7 масс. \% соответственно (табл. 1).

Результаты проведенных ИК-спектроскопических исследований (рис. 2-4) согласуются с данными изменения элементного анализа продуктов аэробной биопереработки этаноллигнина древесины пихты. Полученные спектры исходного этаноллигнина и продуктов его аэробной биопереработки содержат интенсивные широкие п.п. в области 3600-2500 см-1, обусловленные валентными колебаниями связанной воды и различными типами ОН-групп; в области 


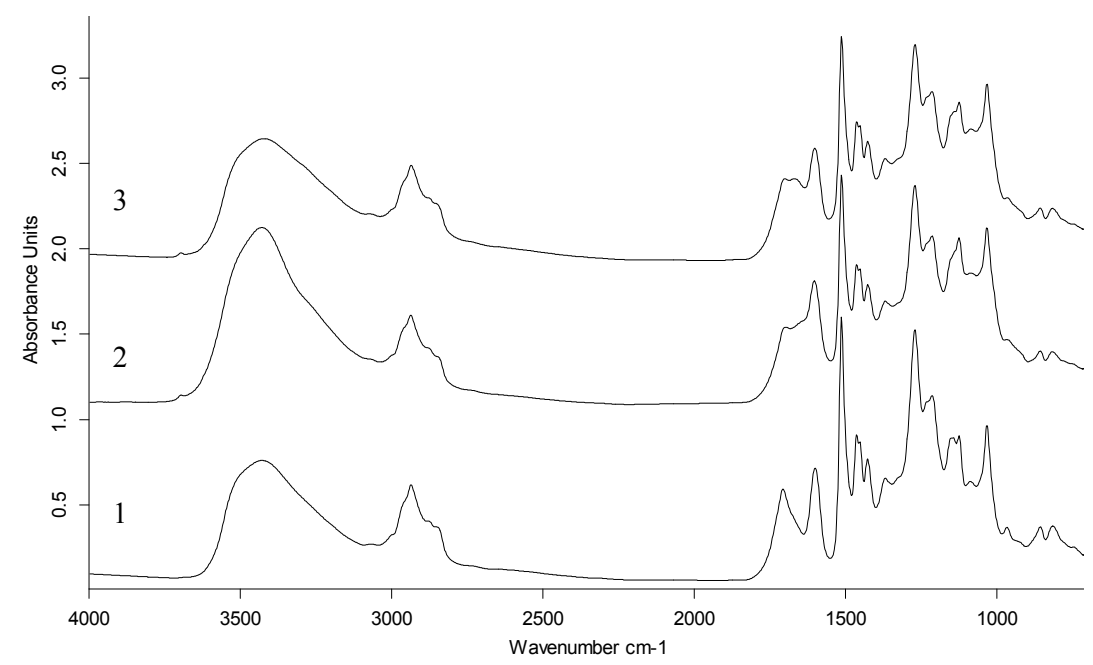

Рис. 2. ИК-спектры продуктов аэробной переработки этаноллигнина: 1 - исходный ЭЛ; 2 - микроскопическими грибами Penicillium + Aspergillus (образец 1); 3 - смешанной культурой бактерий и грибов Pseudomonas sp. + Agrobacterium sp. + Penicillium (образец 2)

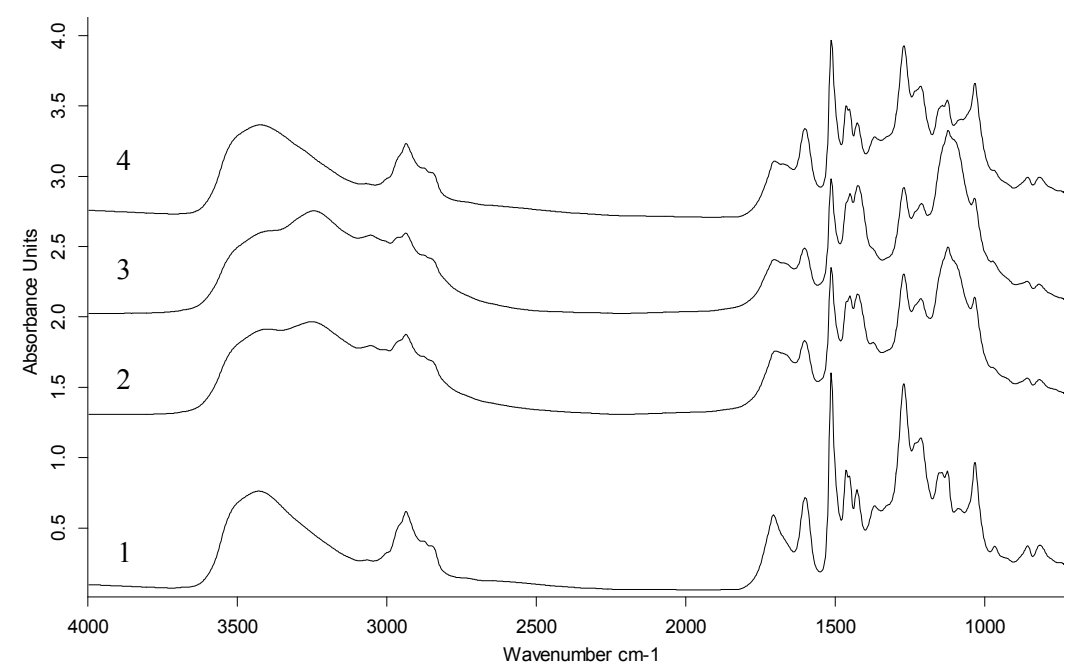

Рис. 3. ИК-спектры продуктов аэробной переработки этаноллигнина бактериями: 1 - исходный ЭЛ; 2 - Pseudomonas sp. (образец 3); 3 - Pseudomonas sp. + Actinomicetus (образец 4); 4 - Pseudomonas sp. + + Agrobacterium sp. (образец 5);

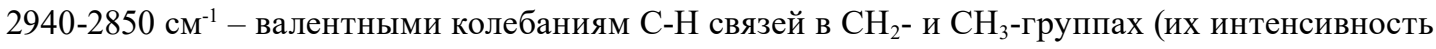
уменьшается при аэробной обработке ЭЛ), в области 1200-1000 см - деформационными колебаниям С-Н связей и валентными колебаниями С-О-связи.

В области 1710-1400 см-1 п.п. характеризуют валентные колебания групп с кратными связями: $\mathrm{C}=\mathrm{O}$ (кетонов, сложных эфиров, ароматических карбоновых кислот), $\mathrm{C}=\mathrm{C}, \mathrm{C}_{\mathrm{ar}}-\mathrm{C}_{\mathrm{ar}}$; здесь

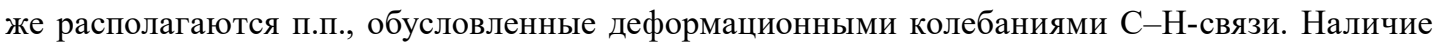
п.п. $3030 \mathrm{~cm}^{-1}, 1605 \mathrm{~cm}^{-1}, 1510 \mathrm{~cm}^{-1}, 1425 \pm 5 \mathrm{~cm}^{-1}$ свидетельствует о присутствии ароматических структур в составе изучаемых образцов. 


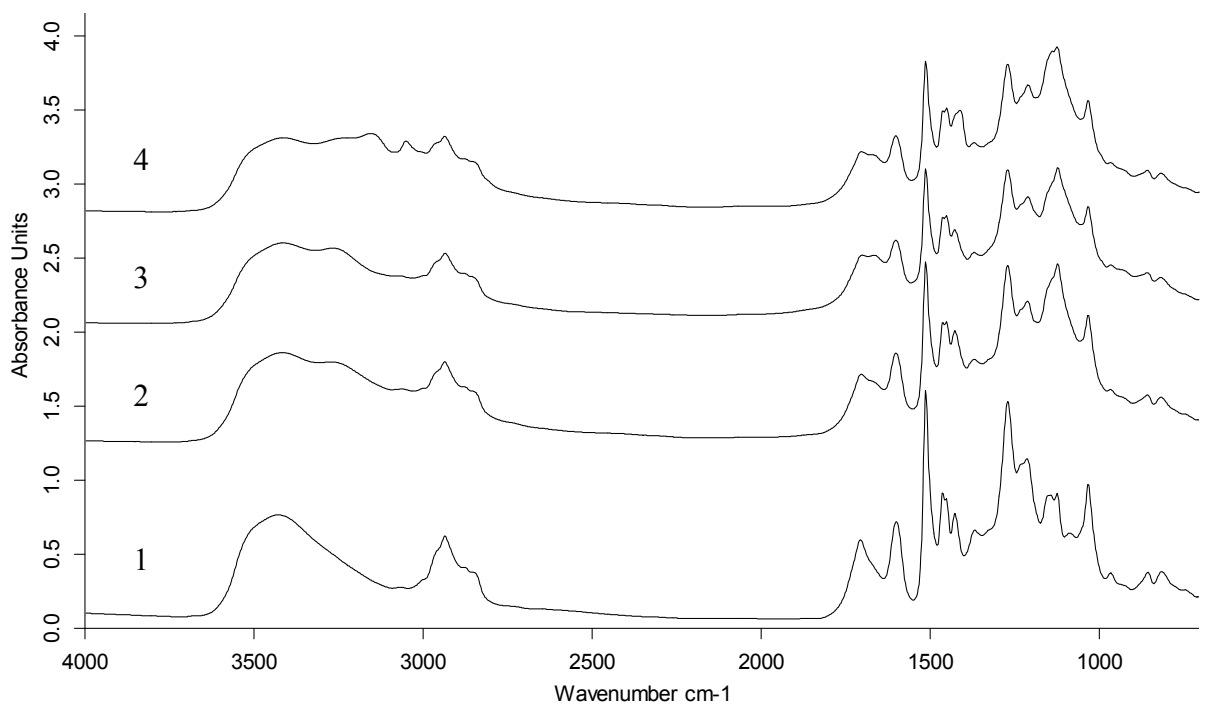

Рис. 4. ИК-спектры продуктов аэробной переработки этаноллигнина бактериями Pseudomonas sp. + Bacillus subtilis + Acinetobacter calcoaceticus ВКПM B-4833 при различной продолжительности процесса: 1 - исходный ЭЛ; 2 - 24 ч (образец 6); 3 - 48 ч (образец 7); 4 - 60 ч (образец 8)

Таблица 2. Соотношение интегральной интенсивности полос поглощения структурных фрагментов ${ }^{*}$ в образцах этаноллигнина

\begin{tabular}{|l|c|c|c|}
\hline \multicolumn{1}{|c|}{ Образец } & $\mathrm{H} / \mathrm{G}$ & $\mathrm{H} / \mathrm{S}$ & $\mathrm{G} / \mathrm{S}$ \\
\hline Исходный ЭЛ & 0,9 & 12,2 & 13,3 \\
\hline Penicillium + Aspergillus (1) & 0,8 & 6,5 & 8,0 \\
\hline Pseudomonas sp.+ Agrobacterium sp. + Penicillium (2) & 0,8 & 8,6 & 10,7 \\
\hline Pseudomonas sp. (3) & 0,7 & 6,0 & 8,3 \\
\hline Pseudomonas sp. + Actinomicetus (4) & 0,7 & 6,5 & 9,4 \\
\hline Pseudomonas sp. + Agrobacterium sp. (5) & 1,0 & 12,5 & 12,7 \\
\hline $\begin{array}{l}\text { Pseudomonas sp. }+ \text { Bacillus subtilis }+ \text { Acinetobacter calcoaceticus BКПM } \\
\text { B-4833, 24 ч (6) }\end{array}$ & 0,8 & 6,8 & 8,1 \\
\hline $\begin{array}{l}\text { Pseudomonas sp. }+ \text { Bacillus subtilis }+ \text { Acinetobacter calcoaceticus BКПM } \\
\text { В-4833, 48 ч (7) }\end{array}$ & 0,6 & 4,8 & 7,9 \\
\hline $\begin{array}{l}\text { Pseudomonas sp. }+ \text { Bacillus subtilis }+ \text { Acinetobacter calcoaceticus BКПM } \\
\text { B-4833, 60 ч (8) }\end{array}$ & 0,7 & 5,2 & 7,3 \\
\hline
\end{tabular}

* - структурные фрагменты: Н-типа - 1605 см$^{-1}$; G-типа - 1270 см$^{-1}$; S-типа - 1125 см$^{-1}$.

Этаноллигнин и продукты его аэробной переработки имеют в своем составе три типа моноядерных арилпропановых структур: гидроксифенил- (Н) (п.п. средней интенсивности при $\approx 1600 \mathrm{~cm}^{-1}$ ), гваяцил- (G) (п.п. при 1033 и $1270 \mathrm{~cm}^{-1}$ ) и сирингилпропановых (S) (п.п. $\approx 1125 \mathrm{~cm}^{-1}$ ). Поскольку в ИК-спектрах всех образцов интенсивность п.п. $1600 \mathrm{~cm}^{-1}$ значительно ниже интенсивности п.п. $1513 \mathrm{~cm}^{-1}$, то исследуемые объекты можно отнести к несопряженным моделям гваяцильного типа. Содержание структурных фрагментов H-, G- и S-типа меняется при аэробной переработке (табл. 2). 
В области 900-800 см$^{-1}$ проявляются внеплоскостные деформационные колебания

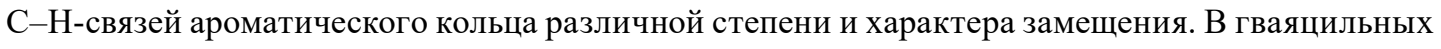
соединениях видны две полосы, характеризующие колебания одного или двух атомов водорода - п.п. с максимумами 856 и $815 \mathrm{~cm}^{-1}$.

Сравнительный анализ ИК-спектров исходного этаноллигнина и продуктов его аэробной переработки микроскопическими грибами Penicillium + Aspergillus (образец 1) и смешанной культурой бактерий и грибов Pseudomonas sp. + Agrobacterium sp. + Penicillium (образец 2) (рис. 2) показывает, что в результате воздействия грибов и бактерий происходит уменьшение интенсивности п.п. валентных колебаний $\mathrm{C}=\mathrm{O}$-группы в несопряженных кетонах, альдегидах и карбоновых кислотах при $1707 \mathrm{~cm}^{-1}$. В то же время в этих спектрах появляется новая полоса п.п. при 1650 и $1670 \mathrm{~cm}^{-1}$ соответственно, которую можно отнести к валентным колебаниям $\mathrm{C}=\mathrm{O}$-группы в различных сопряженных кетонах.

В образцах 3-5 уменьшается содержание алифатических $\mathrm{CH}_{2}$ - и $\mathrm{CH}_{3}$-групп, об этом свидетельствует снижение интенсивности п.П. в области 2980-2780 см$^{-1}$.

Как и в случае образцов 1 и 2, наблюдается уменьшение интенсивности п.п. валентных колебаний $\mathrm{C}=\mathrm{O}$-группы для несопряженных кетонов, альдегидов и карбоновых кислот при $1704 \mathrm{~cm}^{-1}$ и появляется новая полоса п.п. при $1670 \mathrm{~cm}^{-1}$, которая свидетельствует о наличии $\mathrm{C}=\mathrm{O}$ в сопряженных кетонах.

В ИК-спектрах образцов 3 и 4 области валентных колебаний ОН-групп наблюдается усложнение спектра - возникают новые п.п. с максимумами 3246, 3054 см$^{-1}$, характеризующие появление ОН-групп, вовлеченных в водородную связь. Увеличение поглощения в области 1200-1050 см-1 может свидетельствовать о появлении С-О-связей.

Обработка ЭЛ бактериями Pseudomonas sp. и смесью бактерий Pseudomonas sp. и Actinomicetus (образцы 3 и 4) приводит к изменению содержания гидроксифенильных, гваяцильных и сирингильных фрагментов (табл. 2). Для образца 5 соотношение этих фрагментов почти не меняется по сравнению с исходным ЭЛ.

На рис. 4 приведены ИК-спектры исходного ЭЛ и его продуктов, получаемых под воздействием смешанной культуры бактерий Pseudomonas sp. + Bacillus subtilis + Acinetobacter calcoaceticus ВКПМ В-4833 в течение 24-60 ч.

Наибольшие изменения образца исходного этаноллигнина происходят в первые 24 ч. С течением времени под действием смеси бактерий происходит уменьшение содержания $\mathrm{CH}_{2}$ и $\mathrm{CH}_{3}$-групп в образцах, появляются новые п.п. в области 4000-3000 см-1, которые можно отнести к валентным колебаниям ОН-групп, вовлеченных в водородную связь. Наблюдается также увеличение поглощения в области 1200-1050 cм-1 - области валентных колебаний $\mathrm{C}-\mathrm{O}-$ связей. В области поглощения связей $\mathrm{C}=\mathrm{O}$ происходят такие же изменения, как и для образцов 1-5.

\section{Выводы}

Проведены исследования по аэробной биопереработке в погружной среде этаноллигнина, выделенного из пихты сибирской, различными микроорганизмами. Установлено, что в процессе аэробного воздействия микроорганизмами происходит активная деструкция этаноллигнина. При продолжительности процесса аэробной биопереработки в течение 8 сут максималь- 
ной активностью при биоконверсии этаноллигнина обладает инокулят, состоящий из бактерий рода Pseudomonas sp. и микроскопических грибов Actinomicetus, для которого конверсия этаноллигнина составила 38,4 масс. \% и скорости конверсии 8,9 г/ч•10-3.

Показано, что использование смешанной культуры бактерий Pseudomonas sp., Bacillus subtilis и Acinetobacter calcoaceticus ВКПМ В-4833 позволило обеспечить близкую степень превращения этаноллигнина, но при уменьшении продолжительности процесса до 24-60 ч. При этом максимальная скорость конверсии этаноллигнина $(67,5$ г/ч•10-3) была достигнута в первые 24 ч.

Определено, что аэробное воздействие использованных микроорганизмов приводит к существенному изменению содержания гидроксифенильных, гваяцильных и сирингильных фрагментов в структуре этаноллигнина. Исключение составляет лишь продукт аэробной переработки этаноллигнина смешанной культурой бактерий Pseudomonas sp. и Agrobacterium sp., в котором менее выражены изменения указанных структурных фрагментов.

Этаноллигнин и продукты его аэробной переработки изучены с использованием приборов Красноярского регионального центра коллективного пользования СО РАН.

\section{Список литературы}

1. Алексеева М.А. Запас лесосырьевых ресурсов в Красноярском крае увеличивается. ЛесПромИнформ 2013. № 5(95). С. 26-29. [Alekseeva M.A. In Krasnoyarsk region the stock of timber resources increases. LesPromInform 2013. № 5(95). Р. 26-32. (In Russ.)]

2. Берлянт А.М., Дронов В.П., Душина И.В. и др. География: Справ. материалы; Под ред. В.П. Максаковского. М.: Просвещение, 2004. 400 с. [Berlyant A.M., Dronov V.P., Dushina I.V. et al. Geography: Handbook. Moscow: Prosveshchenie, 2004. 400 p. (In Russ.)]

3. Степень Р.А., Репях С.М. Альтернативные пути рациональной переработки древесных отходов. Инвестиционный потенциал лесопромышленного комплекса Красноярского края. Сб. статей научно-практической конференции. 5-6 сентября 2001 г. Красноярск: СибГТУ, 2001. C. 116-120. [Stepen' R.A., Repyakh S.M. Alternative routes of rational processing of wood waste. Investment potential of a timber industry complex of the Krasnoyarsk region. Book of articles of scientific-practical conference. 5-6 September 2001. Krasnoyarsk: SibGTU, 2001. P. 116-120. (In Russ.)]

4. Кузнецов Б.Н., Левданский В.А., Кузнецова С.А. Химические продукты из древесной коры. М-во образования и науки Рос. Федерации, Сиб. федер. ун-т. Красноярск: СФУ, 2012. 259 c. [Kuznetsov B.N., Levdansky V.A., Kuznetsova S.A. Chemical products from wood bark. Department of Education and Science, Siberian federal university. Krasnoyarsk: SFU, 2012. 259 p. (In Russ.)]

5. Фенгел Д., Вегнер Г. Древесина, химия, ультраструктура, реакиии. М.: Лесная промышленность, 1988. 512 с. [Fengel D., Vegner G. Wood, chemistry, ultra-structure, reactions. Moscow.: Forest industry, 1988. 512 p. (In Russ.)]

6. Азаров В.И., Буров А.В., Оболенская А.В. Химия древесины и синтетических полимеров. СПб.: Издательство «Лань», 2010. 624 с. [Azarov V.I., Burov A.V., Obolenskya A.V. Wood and synthetic polymers chemistry. SPb: "Lan” Publishing House. 2010. 624 p. (In Russ.)] 
7. Рязанова Т.В., Чупрова Н.А., Исаева Е.В. Химия древесины. Красноярск: СибГТУ, 2011. 389 c. [Ryazanjva T.V., Chuprova N.A., Isaeva E.V. Wood chemistry. Krasnoyarsk: SibGTU. 2011. 389 p. (In Russ)]

8. Грушников О.П., Антропова О.Н. Микробиологическая деградация лигнина. Усneхи химии 1975. T. XLIV. Вып. 5. С. 935-967. [Grushnikov O.P., Antropova O.N. Microbiological degradation of lignin. Russian Chemical Reviews 1975. V. XLIV. Is. 5. P. 935-967. (In Russ.)]

9. Рабинович М.Л., Болобова А.В., Кондращенко В.И. Теоретические основы биотехнологии древесных композитов. Кн. 1. Древесина и разрушающие ее грибы. М.: Наука, 2001. 264 c. [Rabinovich M.L., Bolobova A.V., Kondrashchenko V.I. Theoretical basis of wood composite biothecnology. Book 1. Wood and destroy it fungi. Moscow: Nauka, 2001. 264 p. (In Russ.)]

10. Кузнецов А.Е., Градова Н.Б. Научные основы экобиотехнологии. М.: Мир, 2006. 504 с. [Kuznetsov A.E., Gradova N.B. Scientific basis of ecobiotechnology. Moscow: Mir, 2006. 504 p. (In Russ.)]

11. Bholay A.D., Bokhataria Bravna V., Jadhad Priyanka U. et al. Bacterial lignin peroxidase: A tool for biobleaching and biodegradation of industrial effluents. Univ. J. Environ. Res. Technol. 2012. V. 2. № 1. P. 58-64.

12. Петров С.В., Купряшина М.А., Глинская Е.В., Никитина В.Е. Лигнин-пероксидаза фенолоксидазного комплекса ассоциативных бактерий Azospirillum Brasilense. Вестник Оренбургского государственного университета 2014. Вып. 13(174). № 12. C. 75-77. [Petrov S.V., Kupryashina M.A., Glinskya E.V., Nikitina V.E. Lignin peroxidase of phenoloksidaze complex of associated bacteria. Bulletin of Orenburg State University 2014. Is. 13(174). No. 12. P. 75-77. (In Russ.)]

13. Мокрушина Н.С., Тарасова Т.С., Дармов И.В. Выделение микромицетов, перспективных для разработки на их основе биопрепарата для ускоренной переработки древесных отходов в удобрения. Вестник Нижегородского университета им. Н.И. Лобачевского 2010. № 2(2). C. 430-434. [Mokrushina N.S., Tarasjva T.S., Darmov I.V. Isolation of micromycetes which are promising in developing a biopreparation for speeding up the composting of wood wastes into fertilizres. Bulletin of Lobachevsky State University of Nizhni Novgorod 2010. No. 2(2). P. 430-434 (In Russ.)]

14. Kersten P., Cullen D. Extracellular oxidative systems of the lignin-degrading Basiodiomycete Phanerochaete chrysosporium. Fungal Genetics and Biology 2007. V. 44. P. 77-87.

15. Явметдинов И.С., Степанова Е.В., Гаврилова В.П. и др. Получение и характеристика гуминоподобных веществ, синтезируемых дереворазрушающими грибами, возбудителями «белой гнили». Прикладная биохимия и микробиология 2003. T. 39. № 3. C. 293-301. [Yavmetdinov L.S., Stepanova E.V., Gavrilova V.P. et al. Isolation and characterization of humin-like subsnances produced by wood-degrading fungi causing white rot. Applied Biochemistry and microbiology 2003. V. 39. No. 3. P. 293-301. (In Russ.)]

16. Koroleva O.V., Gavrilova V.P., Stepanova E.V. et al. Production of lignin modifying enzymes by co-cultivated white route Cerrena maxima and Coriollus hirsutus and characterization of laccase from Cerrena maxima. Enzyme and Microbiol. Technology 2002. V. 30. No. 4. P. 573-580.

17. Koroleva O.V., Stepanova E.V., Gavrilova V.P. et al. Laccase and Mn-peroxidase production by Coriollus hirsutus strain 075 in jar fermenter. J. Bioscience and Bioengineering 2002. V. 93. No. 5. P. 449-455. 
18. Zadrazill F., Brunnert H. The influence of ammonium nitrate supplementation on degradation and in vitro digestibility of straw colonized by higher fungi. European Journal of Applied Microbiology and Biotechnology 1980. V. 9. P. 37-44.

19. Головлева Л.А., Мальцева О.В., Мясоедова Н.М. и др. Оценка влияния различных способов предобработки растительных субстратов на лигнолитическую активность гриба Рanus tigrinus 144. Химия древесины 1988. № 2. C. 66-71. [Golovleva L.A., Maltseva O.V., Myasoedova N.M. et al. The impact estimation of different methods of pre-treatment plant substrates lignolitic fungus activity Panus tigrinus 144. Wood chemistry 1988. No. 2. P. 66-71. (In Russ.)]

20. Ревин В.В., Атыкян Н.А., Кадималиев Д.А. Способ биоконверсии отходов растительного сырья. Пат. 2255979 РФ. 2003. [Revin V.V., Atakyan N.A., Kadimaliev D.A. The process of bioconversion of waste plant raw materials. Pat. 2255979 RU (In Russ.)]

21. Княгина Ю.П., Смирнов В.Ф., Стручкова И.В. и др. Биодеструкция лигнина из древесностружечных плит микроскопическими грибами. Химия растительного сырья 2005. № 4. С. 4144. [Knyagina Yu.P., Smirnov V.F., Struchkova I.V. et al. Biodegradation of lignin from wood chipboard microscopic fungi. Chemistry of plant raw materials 2005. No. 4. P. 41-44. (In Russ.)]

22. Рязанова Т.В., Чупрова Н.А., Лунева Т.А. Воздействие гриба рода Trichoderma на лигнин коры древесных пород. Катализ в промышленности 2014. № 6. C. 64-70. [Ryazanova T.V., Chuprova N.A., Luneva T.A. Effect on Trichoderma fungi on bark lignin. Catalysis in industry 2014. No. 6. P. 64-70.(In Russ.)]

23. Kim D.E., Pan X. Preliminary study on converting hybrid poplar to high-value and lignin using ethanol process. Ind.Eng. Chem. Res. 2010. V. 49. P. 12156-12163.

24. Pan X., Xie D., Yu R.W., Lam D., Saddler J.N. Pretreatment of lodgepole pine killed by mountain beetle using the ethanol organjsolv process: fractionation and process optimisation. Ind.Eng. Chem. Res. 2007. V. 46. P. 2609-2617.

25. Wildschut J., Smit A., Reith J., Huijgen W.J. Ethanol-based organosolv fractionation of wheat straw for the production of lignin and enzymatically digestible cellulose. Bioresource Technology. 2013. V-135, May. P. 58-66.

26. Орлов Д.С. Химия почв. М.: МГУ, 1985. 376 c. [Orlov D.S. Chemistry of soils. Moscow: MGU, 1985. 376 p. (In Russ.)]

27. Оболенская А.В., Ельницкая 3.П., Леонович А.А. Лабораторные работы по химии древесины и целлюлозы. М.: Экология, 1991. 320 с. [Obolenskya A.V., El'nitskya Z.P., Leonovich A.A. Laboratory works on chemistry of wood and cellulose. Moscow: Ecology, 1991. 320 p. (In Russ.)]

28. Беллами Л. Новые данные по ИК-спектроскопии сложных молекул. М.: Мир, 1971. 365 c. [Bellamy L. New data on IR spectroscopy of complex molecules. Moscow: Mir, 1975. 365 p. (In Russ.)]

29. Conley R.T. Infrared spectroscopy. Boston: Allyn and Bacon, 1972. 355 p.

30. Faix O. Investigation of lignin polymer models (DHP's) by FTIR spectroscopy. Holzforschung, 1986. V. 40. No. 46. P. 273-280.

31. Lin S.Y., Dence C.W. Methods in lignin chemistry. Springer-Verlag, 1992. 578 p.

32. Хергерт Г.Л. ИК-спектры лигнина. Лигнины; Под ред. К.В. Сарканена и К.Х. Людвига. М.: ИЛ, 1975. 632 с. [Khergert G.L. IR spectrums of lignin. Lignins; Ed. by K.V.Sarkanen and K.Kh.Lyudvig. Moscow: IL, 1975. 632 p. (In Russ.)] 
33. Евстафьев С.Н., Чечикова Е.В. Состав продуктов делигнификации соломы пшеницы в условиях субкритического автогидролиза. Вестник Иркутского государственного технического университета. 2015. № 11 (106). C. 111-118 [Evstafiev S.N., Chechikova E.V. The composition of the products of delignification of wheat straw under conditions of subcritical autohydrolysis. Vestnik of Irkutsk state technical University 2015. No. 11 (106). P. 111-118 (In Russ.)] 